\title{
Maintenance of vascular integrity: role of nitric oxide and other bradykinin mediators
}

\author{
F. COSENTINO AND T. F. LÜSChER
}

\author{
Division of Cardiology, Cardiovascular Research, University Hospital, Bern, Switzerland
}

KEY WORDS: Angiotensin converting enzyme inhibitors, cardiovascular disease, endothelium-derived relaxing factors, L-arginine/nitric oxide pathway, nitric oxide, vascular homeostasis.

In the blood-vessel wall, the endothelium plays a key functional role by generating several substances that modulate vascular smooth muscle tone, as well as growth, and platelet function. This review focuses on the role of the endothelial L-arginine/nitric oxide signal transduction pathway in the maintenance of vascular integrity. Functional alterations of this pathway may be important in cardiovascular disease, because depressed activity of this protective mechanism leads to impaired relaxation and is also associated with reduced antithrombotic properties of the endothelial layer. Many of the beneficial effects of ACE inhibitor therapy may be mediated through their ability to enhance the physiological roles of nitric oxide.

\section{Introduction}

Nitric oxide is a vasodilator and potent inhibitor of platelet function that is synthesized from $L$-arginine by nitric oxide synthase. Nitric oxide enters adjacent smooth muscle cells, leading to increased generation of cyclic guanosine monophosphate and, subsequently, to vascular relaxation. Nitric oxide-mediated vascular dilation is constant, as endothelial cells continuously release small amounts of this relaxing factor. Studies have shown that a basal level of nitric oxide production, as well as agonist-stimulated production, plays a key role in the regulation of vascular tone. Thus, endothelial generation of nitric oxide is involved in the maintenance of normal blood flow and pressure. Given its ability to keep the vascular smooth muscle surface nonadhesive and nonthrombogenic for circulating blood cells, nitric oxide prevents platelet adhesion and aggregation. Depressed activity of the L-arginine/nitric oxide pathway leads to impaired relaxation (vasoconstriction and reduced local blood flow) and is associated with reduced antithrombotic properties of the endothelium. In disease states such as hypertension, endothelium-dependent relaxation may be impaired, despite evidence of increased nitric oxide release. Its haemodynamic roles may be diminished by production of oxidative radicals or other disease-related factors.

In patients with atherosclerosis, the response to endothelium-dependent vasodilators, including nitric oxide, may be impaired, possibly due to increased formation of superoxide radicals or interference by oxidized lowdensity lipoprotein with the L-arginine/nitric oxide pathway. Angiotensin I converting enzyme (ACE) plays a key role in vascular homeostasis. Pharmacological inhibition of ACE not only prevents the formation of the powerful vasoconstrictor angiotensin II, but augments local concentrations of bradykinin, a potent stimulator of the

Correspondence. Thomas F. Luscher, MD, Division of Cardiology, Cardiovascular Research, University Hospital, CH 3010 Bern, Switzerland.
L-arginine/nitric oxide pathway, thereby enhancing vasodilation. Studies have demonstrated improved endothelial function with these agents, as well as inhibition of platelet aggregation.

Thus the protective effects of ACE inhibitors in various cardiovascular disease states may be attributable to enhancement of the physiological roles of nitric oxide.

\section{The endothelium and vascular homeostasis}

Endothelial cells, which line the intimal surface of blood vessels, play an important role in many physiological processes. They perform a variety of functions, including transportation of water and solute regulation of plasma lipids, participation in inflammatory and immunological reactions, maintenance of the fluidity of blood, and adjustment of the calibre of blood vessels to the ever-changing haemodynamic and hormonal environment. Because of their strategic anatomical location between circulating blood and tissues, endothelial cells have the capacity to sense changes in haemodynamic forces (shear forces and pressure) and in locally produced or circulating mediators, and to respond to these changes by the production of a number of biologically active factors. The endothelium is regarded as one of the most important, and certainly the most extensive, 'organ' in the body that participates in cardiovascular homeostasis.

The seminal observation of Furchgott and Zawadzki ${ }^{[1]} 15$ years ago, that endothelial cells play an obligatory role in the relaxation evoked by acetylcholine in isolated rabbit aortas, not only stimulated research activity worldwide but truly revolutionized cardiovascular sciences. Now, endothelium-dependent regulation of vascular tone (local regulation of blood flow), platelet function, and mitogenesis (antithrombotic mechanisms) have become a key part of our view of cardiovascular physiology. Perhaps even more important, the achievements in recent years have led to a better understanding of the pathophysiology of hyper- 


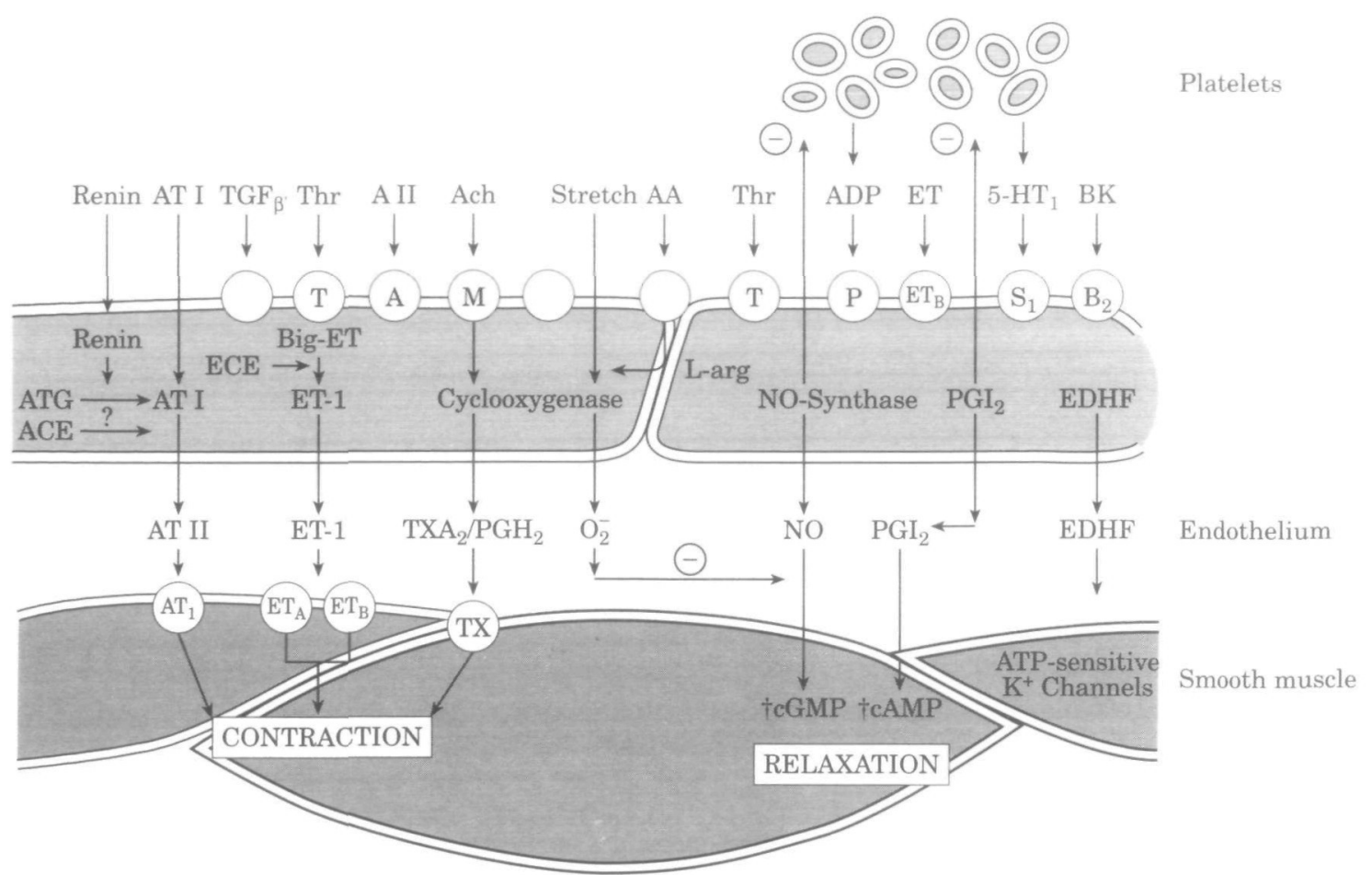

Figure 1 Schematic diagram showing endothelium-derived vasoactive factors produced in blood vessels.

tension, vasospasm, and atherosclerosis and to new therapeutic strategies to fight these pathological conditions.

Indeed, a number of endothelium-derived factors can profoundly modify platelet function as well as the contractile and proliferative state of vascular smooth muscle cells ${ }^{[2]}$. These factors include nitric oxide and prostacyclin, which are both vasodilators and potent inhibitors of platelet function, and a putative endothelium-derived hyperpolarizing factor. By contrast, endothelial cells can also produce vasoconstrictors and growth promoters, such as thromboxane $A_{2}$, prostaglandin $\mathrm{H}_{2}$, endothelin, and angiotensin II (Fig. 1).

This review will focus on the current knowledge concerning the role of the nitric oxide signal transduction pathway in the maintenance of vascular integrity.

\section{L-Arginine/nitric oxide pathway}

The demonstration in 1980 of the phenomenon of endothelium-dependent relaxations and of the release of endothelium-derived relaxing factor (EDRF) ${ }^{[1]}$ led to a search for the chemical identity of this factor. In the next few years, EDRF was shown to be an extremely labile molecule ${ }^{[3]}$ and some of its properties were described. Eventually, it was shown that vascular endothelial cells release nitric oxide and that this compound accounted for the vasodilatory and platelet inhibitory effects of $E$ RF $^{(4)}$. Nitric oxide is synthesized from L-arginine by nitric oxide synthase (NOS) through a five-electron oxidation of the guanidine-nitrogen terminal of L-arginine ${ }^{|s|}$. Many advances in the understanding of the $L$-arginine/nitric oxide pathway have come from molecular studies of NOS. Three distinct genes encoding different NOS isoforms have been cloned. Neuronal NOS was the first form of the enzyme to be purified and cloned ${ }^{[6]}$. More recently, both endothelial ${ }^{[7-9]}$ and macrophage forms have also been cloned ${ }^{[0-12]}$. Macrophages have negligible NOS activity under basal conditions, but after stimulation with lipopolysaccharide and/or cytokines, massive increases in NOS activity occur within 2 to $4 \mathrm{~h}^{[13-16]}$. The macrophage enzyme, which is calcium independent, has thus been referred to as 'inducible NOS' (iNOS) in contrast to the enzyme in neuronal tissues or endothelium, which appears to be constitutively expressed.

Many cell types throughout the body, including hepatocytes, neurons, neutrophils, endothelial cells, vascular smooth muscle cells, and cardiac myocytes, appear capable of iNOS expression ${ }^{[17-19]}$. Once expressed, the inducible isoform generates large amounts of nitric oxide over an extended period of time $(48 \text { to } 72 \mathrm{~h})^{[20]}$. In humans, iNOS has been found to be expressed in a variety of cytokine-induced pathologic states, including tumors ${ }^{[21]}$, cirrhosis $^{[2]}$, ulcerative colitis ${ }^{[2]}$, and endotoxemic shock ${ }^{[24]}$.

To understand the role of NOS in vascular physiology and pathology, discrimination between the involvement of the various isoforms of NOS may be important.

Constitutive NOS synthesizes nitric oxide within seconds in response to ligand-receptor-coupling events at the cell surface and displays a strict dependence on $\mathrm{Ca}^{2+}$ and calmodulin ${ }^{[25-27]}$. In vascular endothelium, $\mathrm{Ca}^{++}$may be made available through stimulation by agonists such as acetylcholine and bradykinin, which generate inositol 1,4,5triphosphate $\left(\mathrm{IP}_{3}\right)$ production via activation of the so called 'phosphoinositide second messenger system'. $\mathrm{IP}_{3}$ elicits $\mathrm{Ca}^{2+}$ release from intracellular stores by binding to $\mathrm{IP}_{3}$ receptors on the endoplasmic reticulum (Fig. 2). Furthermore, a portion of mobilized $\mathrm{Ca}^{2+}$ is thought to arise 


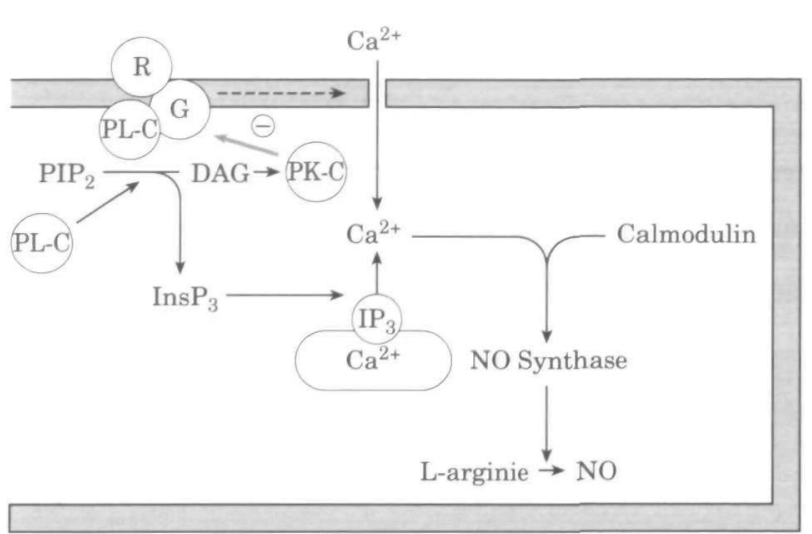

Figure 2 Pathways that can increase intracellular calcium in endothelial cells, which in turn leads to activation of nitric oxide synthase: phospholipase $\mathrm{C}$ activation by receptor and $\mathrm{G}$ protein coupling; influx of extracellular calcium. (Modified from ${ }^{[12]}$.)

extracellularly. Alternatively, agonist-independent nitric oxide release also contributes to vascular tone. Both shear stress ${ }^{[28]}$ and deformation of endothelium ${ }^{[29]}$, due to pulsatile flow in blood vessels, stimulate nitric oxide release through poorly characterized mechanisms. Once released, nitric oxide enters adjacent smooth muscle cells, where it activates soluble guanylate cyclase to generate cyclic guanosine monophosphate (cGMP). The increased concentration of cGMP in these cells causes vascular relaxation ${ }^{[30)}$.

\section{Physiological roles of nitric oxide}

\section{REGULATION OF VASCULAR TONE}

The vasculature is in a constant state of active dilation mediated by nitric oxide. Endothelial cells continuously release small amounts of nitric oxide, producing a basal level of vascular smooth muscle relaxation. However, the expression of constitutive enzyme and the release of nitric oxide can be enhanced above basal levels after receptor stimulation by different agonists. Both in vitro and in vivo studies have demonstrated that basal and stimulated production of nitric oxide in endothelial cells plays a key role in the regulation of vascular tone. The strongest evidence comes from results obtained in studies with $\mathrm{N}^{\mathrm{a}}$-substituted analogs of L-arginine, which are potent and selective inhibitors of nitric oxide synthesis (Fig. 3) ${ }^{\mid 5311}$. L-Arginine analogs, such as $\mathrm{N}^{\mathrm{G}}$-monomethyl-L-arginine (L-NMMA), $\mathrm{N}^{\mathrm{G}}$-nitro-L-arginine-methyl ester (L-NAME) and $\mathrm{N}^{\mathrm{G}}$-nitroL-arginine (L-NA), cause endothelium-dependent contractions in a number of isolated arteries. These contractions are mediated by inactivation of basal production of nitric oxide $^{[5,32,33]}$. The inhibitory effect of these compounds is prevented by $\mathrm{L}$-arginine (but not $\mathrm{D}$-arginine). This stereospecific inhibition indicates that L-arginine analogs compete with L-arginine for the NOS active site to prevent production of nitric oxide. Intravenous injections of L-NMMA into anaesthetized rabbits resulted in an immediate and substantial rise in blood pressure, which could be reversed by $L$-arginine ${ }^{[34]}$. The blood pressure-elevating and vasoconstrictive effects of L-NMMA have now been demonstrated in a number of species, including man ${ }^{[35-3 \pi]}$.
Similar results have been obtained with the other known NOS inhibitors ${ }^{[38]}$. These inhibitors have no intrinsic constrictor activity on vascular smooth muscle; their activity is entirely endothelium dependent and results from the inhibition of endogenous vasodilatation.

Thus, it appears that the endothelial generation of nitric oxide by NOS is involved in the maintenance of normal blood flow and pressure. The observations that in porcine coronary arteries and in small canine cerebral arteries endothelium-dependent relaxations to bradykinin are resistant to inhibitors of nitric oxide formation or cyclooxygenase ${ }^{[39-41]}$ strongly suggest that an endothelium-derived relaxing substance distinct from nitric oxide and prostacyclin is formed as well. Recent studies suggest that bradykinin and acetylcholine hyperpolarize vascular smooth muscle cells in an endothelium-dependent manner ${ }^{[22-45}$. These data would be compatible with the concept that endothelial cells release a biochemically unidentified substance that has the capacity to hyperpolarize vascular smooth muscle cells via adenosine triphosphate-dependent potassium channels ${ }^{[46,47]}$. Hyperpolarization of vascular smooth muscle cells is associated with a decreased sensitivity to vasoconstrictor substances and may also contribute to vasodilator responses induced by prostacyclin and nitric oxide.

\section{INHIBITION OF PLATELET FUNCTION}

Endothelium-derived relaxing factors, such as nitric oxide and prostacyclin, not only serve to relax the underlying smooth muscle but also keep the surface nonadhesive and nonthrombogenic for circulating blood cells. Both mediators increase cGMP and cyclic adenosine monophosphate (cAMP) in platelets and thereby prevent platelet adhesion and aggregation ${ }^{[48-52]}$. In addition, platelets themselves possess an L-arginine/nitric oxide pathway that modulates the reactivity of the cells to aggregatory stimuli[is3].

In isolated human coronary and internal mammary arteries, aggregating platelets cause endothelium-dependent

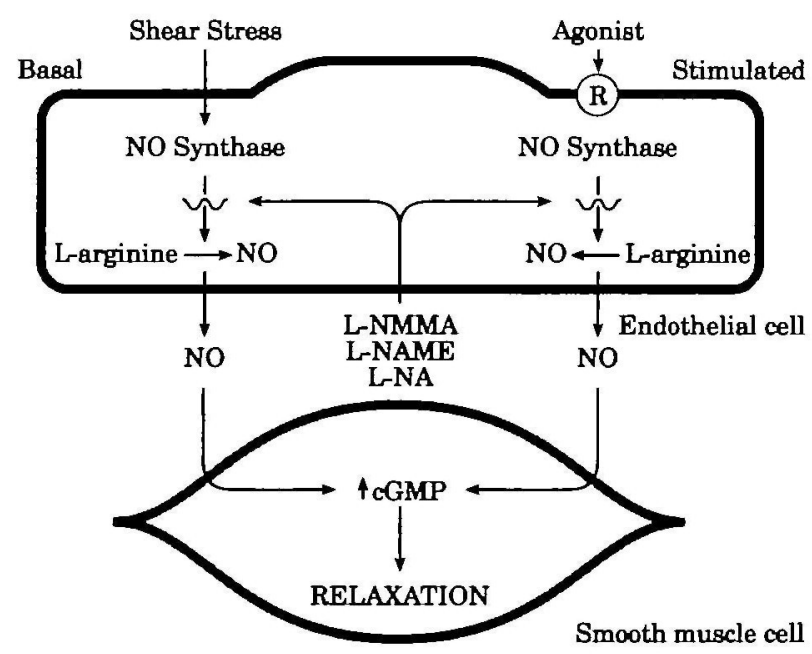

Figure 3 Schematic representation of inhibitory effect of L-arginine analogs on basal and stimulated production of nitric oxide. (Modified from ${ }^{|30|}$.) 
relaxations that are mediated by nitric oxide ${ }^{[54,55]}$. The platelet-derived mediator primarily responsible for the stimulation of nitric oxide formation is adenosine diphosphate, although serotonin may contribute under certain conditions ${ }^{[5657]}$. In contrast to normal arteries, arteries devoid of endothelial cells or with dysfunctional endothelium markedly contract in response to aggregating platelets $^{[55]}$. Platelet-induced vasoconstriction is mediated primarily by serotonin and thromboxane $A_{2}$, which activate specific receptors on vascular smooth muscle cells ${ }^{[55,58]}$. At sites where platelets are stimulated, the coagulation cascade also is activated, leading to the formation of thrombin. Thrombin is an enzyme that is responsible for the formation of fibrin from fibrinogen. In addition to its activity in the coagulation cascade, thrombin is a potent activator of platelets ${ }^{[48]}$, but it also exerts effects in endothelial cells. Indeed, thrombin causes endothelium-dependent relaxations in human coronary arteries and internal mammary arteries ${ }^{[99,60]}$. These relaxations are partially inhibited by indomethacin and L-NAME ${ }^{[39]}$. This indicates that both nitric oxide and prostacyclin contribute to the response. Hence, in the presence of an intact endothelium, thrombin not only causes vasodilatation, but it also inhibits platelet function via an endothelium-dependent mechanism. These effects counteract the direct activating effects of thrombin in platelets and thereby represent a protective negative feedback mechanism, preventing further activation of platelet-vessel wall interaction.

Nitric oxide has also been shown to inhibit leukocyte activation both in vitro and in vivo ${ }^{[61,62]}$. Thus, nitric oxide even appears to be involved in regulating the interactions between leucocytes and the vascular endothelium.

\section{REGULATION OF VASCULAR GROWTH}

Removal of the endothelium by balloon catheter invariably leads to intimal proliferation. This strongly suggests that the presence of endothelial cells exerts an antiproliferative effect ${ }^{\left[{ }^{33}\right]}$, which may be related to the fact that endothelial cells inhibit the adhesion and aggregation of circulating platelets ${ }^{[48-51]}$ and of monocytes ${ }^{[64]}$, both important sources of platelet-derived growth factor and transforming growth factor beta- $1^{[65]}$. Furthermore, endothelial cells produce inhibitors of migration and proliferation, such as nitric oxide ${ }^{[6,67]}$ and heparin-like substances ${ }^{[68]}$, as well as transforming growth factor beta-1, which under certain conditions is an inhibitor of vascular proliferation ${ }^{[6,70]}$. On the other hand, endothelial cells can also produce growth promoters, such as platelet-derived growth factor, basic fibroblast growth factor, and endothelin-1 $1^{[69,71,72]}$. Thus, the secretion of growth inhibitors or promoters by endothelial cells, as well as their capacity to inhibit circulating blood cells, modulates vascular structures ${ }^{[63]}$.

\section{Nitric oxide in cardiovascular disease}

Functional alterations of the endothelial L-arginine/nitric oxide pathway may be important in cardiovascular disease, because a depressed activity of this protective mechanism would lead to impaired relaxation (vasoconstriction and reduced local blood flow) and be associated with reduced antithrombotic properties of the endothelial layer. Hypertension and atherosclerosis are well-recognized pathophysiological contributors to the progression of cardiovascular disease.

\section{HYPERTENSION}

The role of endothelium in hypertension is still controversial. The endothelium-dependent relaxations are heterogeneously affected in this condition. In some vascular beds of hypertensive rats, such as the aorta and mesenteric, carotid, and cerebral vessels, endothelium-dependent relaxations are impaired ${ }^{[73-75]}$. In contrast, in coronary and renal arteries of spontaneously hypertensive rats (SHR), endothelial function does not seem to be affected by high blood pressure ${ }^{[75,76]}$. Although the endothelium-dependent relaxations are either diminished or normal in spontaneous hypertension, the production of nitric oxide seems to be increased. The release of breakdown products of nitric oxide $\left(\mathrm{NO}_{2}-\mathrm{NO}_{3}\right)$ from isolated coronary vessels is augmented in SHR ${ }^{[n]}$. The activity of constitutive NOS is also enhanced in the SHR heart ${ }^{[78]}$. In addition, it has been demonstrated that pharmacologically induced elevations in blood pressure increase the release of nitric oxide in normotensive rats ${ }^{[79]}$. These data suggest that blood pressure per se is a stimulus for nitric oxide release. This interpretation is reinforced by the fact that constitutive NOS activity is normal in prehypertensive 4-week-old SHR ${ }^{[80]}$. Despite its increased release, nitric oxide is functionally unable to perform its haemodynamic role in the vasculature of genetically hypertensive rats ${ }^{[0]}$, probably because higher production of oxidative radicals, such as superoxide anion, or diminished activity of superoxide dismutase (SOD) accounts for increased degradation of nitric oxide. This effect may contribute to the impaired endothelium-dependent relaxations in this model of hypertension ${ }^{[73]}$. In addition, increased production of endothelium-dependent contracting factors can explain the abnormal endothelial function of some vascular beds.

Nitric oxide production and inactivation might be heterogeneously affected in different forms of hypertension ${ }^{[81]}$. Indeed, in Dahl salt-sensitive rats, endothelium-dependent relaxations are impaired ${ }^{[81,82]}$, but no release of vasoconstrictor prostanoids can be demonstrated. This suggests that decreased nitric oxide production could contribute to the pathogenesis of this form of hypertension.

Studies in humans have demonstrated diminished basal and stimulated nitric oxide production ${ }^{[37.83]}$. The decrease in forearm blood flow induced by L-NMMA is smaller in hypertensive than in normotensive patients ${ }^{[3]}$. Most studies have shown reduced endothelium-dependent vasodilatation in patients with primary or secondary hypertension $^{[8486]}$. The impaired endothelial response in hypertensive patients can be improved by indomethacin, suggesting that vasoconstrictor prostanoids also contribute to impaired endothelium-dependent relaxation ${ }^{[85]}$.

\section{HYPERLIPIDAEMIA AND ATHEROSCLEROSIS}

Although the morphology of the vascular endothelium is not altered in the early stage of atherogenesis ${ }^{[65]}$, its function as a regulator of vascular homeostasis is profoundly 
modified. By contrast, the presence of overt atherosclerosis is associated with morphological changes in the intima of large arteries (intimal thickening, accumulation and proliferation of smooth muscle cells and lipid containing macrophages) ${ }^{[65]}$.

Functional studies report that the response of atherosclerotic arteries to endothelium-dependent vasodilators is impaired at a very early stage in rabbit ${ }^{[87]}$, porcine ${ }^{[88]}$ and human coronary arteries ${ }^{[89]}$, whereas relaxations in response to the nitric oxide-donor molsidomine SIN-1 are well maintained excluding reduced responsiveness of vascular smooth muscle to nitric oxide. In vivo, acetylcholine and serotonin have even produced paradoxical vasoconstriction $^{[58,90]}$. Furthermore, bioassay experiments with atherosclerotic arteries have shown that the release of nitric oxide is reduced in porcine coronary arteries with hypercholesterolaemia and atherosclerosis ${ }^{[91,92]}$. However, recent research in hypercholesterolaemic rabbit aortas has revealed that the production of nitric oxide is markedly enhanced rather than impaired ${ }^{[93,94]}$. The latter observation suggests increased formation of superoxide radicals in the endothelium, inactivating nitric oxide, and/or decreased activity of SOD ${ }^{[95]}$. Indeed, superoxide anion production in these preparations is increased ${ }^{[\$ 6]}$ and treatment with exogenous SOD partially improves endothelium-dependent relaxations of this artery ${ }^{[07]}$.

In the porcine coronary artery, oxidized low-density lipoprotein (ox-LDL) inhibits endothelium-dependent relaxations to different agents, such as platelets, serotonin, and thrombin ${ }^{[9899]}$. This inhibition of endothelium-derived relaxation is specific for ox-LDL, and it is not induced by comparable concentrations of native $\mathrm{LDL}^{[99]}$. A receptor distinct from that for LDL, the scavenger receptor, appears to be activated by ox-LDL, since the endothelial effect of modified LDL can be prevented by dextran sulphate, a competitive antagonist of ox-LDL for this receptor ${ }^{[99]}$.

Oxidized LDL may interfere with the L-arginine pathway, since the inhibition of the endothelium-dependent relax- ation that it produces is similar to that of L-NMMA. However, the effect of ox-LDL can be reversed by L-arginine, suggesting that NOS is not directly affected. Furthermore, the pretreatment of isolated vessels with L-arginine improves endothelial function in response to serotonin that was blunted by ox-LDL. These results suggest that ox-LDL decreases the intracellular availability of L-arginine. Accordingly, in humans with hypercholesterolaemia, L-arginine enhances the blunted increase in local blood flow in response to acetylcholine ${ }^{[100]}$.

\section{Vascular effects of $\mathrm{ACE}$ inhibition}

As indicated above, endothelium-derived mediators regulate vascular integrity. There is evidence that in cardiovascular disease states, the protective role of the endothelium appears to diminish, while the production of vasoconstrictive, proaggregatory, and promitogenic mediators is maintained or enhanced ${ }^{[101,102]}$. One of the enzymes with a key role in vascular homeostasis is angiotensin I converting enzyme (ACE). ACE is located on the endothelial cell membrane and is responsible for the conversion of angiotensin I into angiotensin II as well as for the breakdown of bradykinin.

Bradykinin is a potent stimulator of the L-arginine/nitric oxide pathway ${ }^{[4]}$. Hence, ACE inhibitors not only prevent the formation of a powerful vasoconstrictor with proliferative properties, but also augment the local vascular concentrations of bradykinin and, in turn, the activation of the L-arginine/nitric oxide pathway (Fig. 4) ${ }^{[102-106]}$.

Endothelial function has been shown to be improved by ACE inhibitors in several animal models of cardiovascular disease including $\mathrm{SHR}^{[107]}$ and hypercholesterolaemic rabbits ${ }^{[108]}$, as well as models of experimental heart failure ${ }^{[109]}$.

Several animal models have shown that ACE inhibitors can reduce neointima formation ${ }^{[10,111]}$ following vascular injury. Further analysis of the mechanisms involved in the inhibition of miointimal formation ${ }^{[112]}$ points to a role for

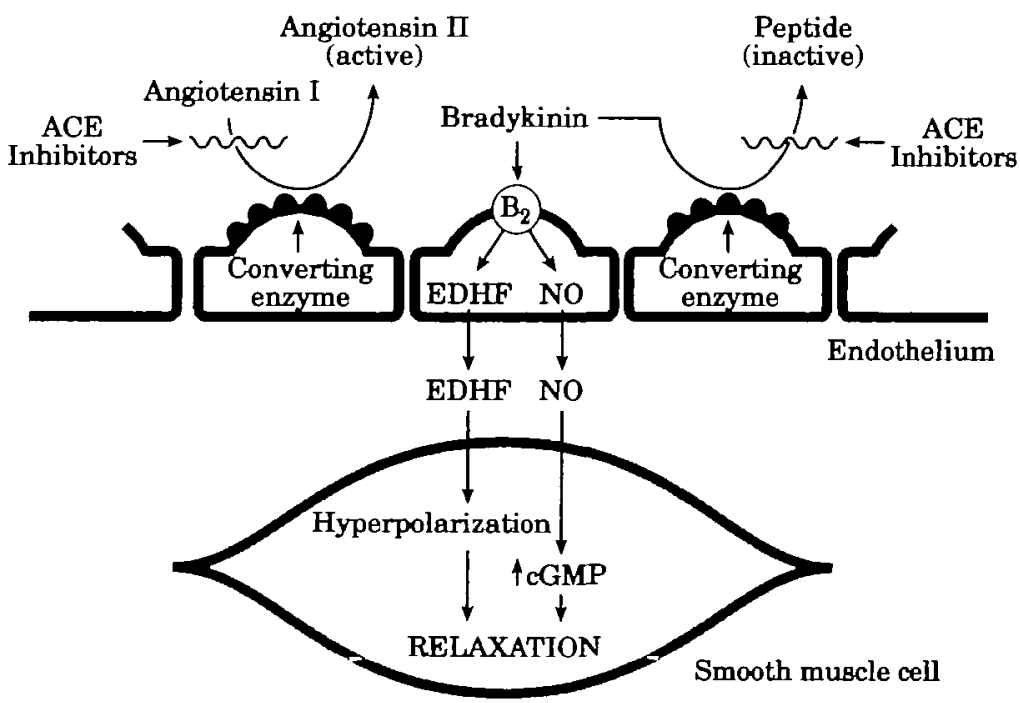

Figure 4 Local vascular effects of ACE inhibitors in the blood vessel wall. ${ }^{[21]}$ 
bradykinin. These findings establish a link between the ability of ACE inhibitors to increase kinin concentrations and their antiproliferative effects following vascular injury. It is likely that the inhibitory effect of kinins on neointima formation is mediated through their stimulation of nitric oxide synthesis, which is known to inhibit smooth muscle cell proliferation and migration ${ }^{[6,67]}$. Another connection between ACE inhibition and the actions of bradykinin is indicated by the finding that the endothelium-dependent relaxation evoked by $\mathrm{ACE}$ inhibition is attenuated by a B2kinin receptor antagonist ${ }^{[113]}$.

Evidence points to the positive activity of ACE inhibitors on arterial thrombosis through their effects on platelet function and the endogenous fibrinolytic system. Several studies have demonstrated inhibition of platelet aggregation by ACE inhibitors ${ }^{[114,115]}$. These inhibitory actions may be related to the inhibition of angiotensin II formation, which is associated with an increase in thrombotic activity. In addition, the increase in bradykinin levels resulting from the inhibition of ACE kininase activity induces the generation of elevated levels of prostacyclin and EDRF, both of which are associated with modulation of platelet aggregation $^{[49]}$. The ability of ACE inhibitors to attenuate platelet aggregation and adhesion may have positive effects in the prevention of atherosclerosis.

ACE inhibitors also appear to have a protective effect against endothelial damage caused by oxygen-derived free radicals. In rabbit aorta, ACE inhibition attenuated the reduction of the vasodilatory response to acetylcholine ${ }^{[116\}}$, normally seen when oxygen-derived free radicals are generated. L-arginine also significantly reduced oxygenderived free radical damage, while L-NA attenuated the protective effects of both ACE inhibitors and L-arginine. The results of this study suggest that the protective effects of ACE inhibitors may be mediated by facilitation of nitric oxide release, with a subsequent reduction in lipid peroxidation.

In recent clinical trials, $\mathrm{ACE}$ inhibitors have been shown to reduce mortality and morbidity in patients with heart failure. In the SOLVD study ${ }^{[17]}$, patients with asymptomatic left ventricular dysfunction who received ACE inhibitors were found to have significantly reduced mortality rates, progression to heart failure, and heart failure-related hospitalizations. In addition, a statistically significant risk reduction for death, MI, and unstable angina of $23 \%$ was observed in the SOLVD population ${ }^{[18]}$. In the SAVE study ${ }^{[119]}, \mathrm{ACE}$ inhibitors administered to patients following myocardial infarction resulted in a $25 \%$ reduction in recurrent myocardial infarction, as well as a $19 \%$ reduction in all-cause mortality. In the more recent AIRE study ${ }^{[120]}$ of more than 2000 patients following myocardial infarction, the all-cause mortality rate was reduced by $27 \%$ over the 15 -month study period. It is interesting to note that the risk reduction was similar in patients with different levels of systolic and diastolic blood pressure at baseline. These observations suggest that the reduction in major ischaemic events seen with ACE inhibition is due, at least in part, to mechanisms separate from their hypotensive effects. Some probable mechanisms include the attenuating effects of ACE inhibitors on the progression of atherosclerosis, stabil- ization of atherosclerotic lesions, inhibition of cardiac hypertrophy and remodelling, and antithrombotic effects.

\section{Conclusions}

In summary, the L-arginine/nitric oxide pathway has undoubtedly reached the clinical arena and is currently under intensive investigation in various forms of cardiovascular disease, including essential hypertension, atherosclerosis, and vasospasm. Many of the beneficial effects of ACE inhibitor therapy may be explained by the inhibition of bradykinin degradation. Thus, ACE inhibition may restore cardiovascular homeostasis, at least in part, by enhancing the physiological roles of nitric oxide.

\section{References}

[1] Furchgott RF, Zawadzki JV. The obligatory role of endothelial cells in the relaxation of artenal smooth muscle by acetylcholine. Nature $1980 ; 288: 373-6$.

[2] Ldischer TF, Tanner FC. Endothelial regulation of vascular tone and growth. Am J Hypertens 1993; 6: 283S-93S.

[3] Griffith TM, Edwards DH, Lewis MJ, Newby AC, Henderson $\mathrm{AH}$. The nature of endothelium-derived vascular relaxant factor. Nature 1984; 308: 645-7.

[4] Palmer RMJ, Ferrige AG, Moncada S. Nitric oxide release accounts for the biological activity of endothelium-derived relaxing factor. Nature $1987 ; 327$ : 524-6.

[5] Moncada S, Palmer RMJ, Higgs EA. Nitric oxide: physiology, pathophysiology, and pharmacology. Pharmacol Rev 1991;43: $109-42$.

[6] Bredt DS, Hwang PH, Glatt C, Lowenstein C, Reed RR, Snyder SH. Cloned and expressed nitric oxide synthase structurally resembles cytochrome P-450 reductase. Nature 1991; 351: 714-8.

[7] Sessa WC, Harrison JK, Barber CM et al. Molecular cloning and expression of a cDNA encoding endothelial cell nitric oxide synthase. J Biol Chem 1992; 267: 15274-6.

[8] Lomas S, Marsden PA, Li GK, Tempst P, Thomas M. Endothelial nitric oxide synthase: molecular cloning and characterization of a distinct constitutive isoform. Proc Natl Acad Sci USA 1992; 89: 6348-52.

[9] Janssens SP, Shimouchi A, Ouertermous T, Bloch DB, Bloch $\mathrm{KD}$. Cloning and expression of a cDNA encoding human endothelium-derived relaxing factor/nitric oxide synthase. J Biol Chem 1992; 267: 14519-22.

[10] Xie Q-W, Cho HJ, Calaycay J et al. Cloning and characterization of inducible nitric oxide synthase from mouse macrophages. Science 1992; 256: 225-8.

[11] Lowenstein CJ, Glatt CS, Bredt DS, Snyder SH. Cloned and expressed macrophage nitric oxide synthase contrasts with brain enzyme. Proc Natl Acad Sci USA 1992; 89: 6711-5.

[12] Lyons CR, Orloff GJ, Cunningham JM. Molecular cloning and functional expression of an inducible nitric oxide synthase from a murine macrophage cell line. J Biol Chem 1992; 267: $6370-4$.

[13] Iyengar R, Stuehr DJ, Marletta MA. Macrophage synthesis of nitrite, nitrate, and $\mathrm{N}$-nitrosamines: precursors and role of the respiratory burst. Proc Natl Acad Sci USA 1987; 84: 6369-73.

[14] Stuehr DJ, Marletta MA. Mammalian nitrate biosynthesis: mouse macrophages produce nitrite and nitrate in response to Escherichia coli lipopolysaccharide. Proc Natl Acad Sci USA $1985 ; 82$ : 7738-42.

[15] Drapier J-C, Hibbs JB Jr. Differentiation of murine macrophages to express nonspecific cytotoxicity for tumor cells results in L-arginine-dependent inhibition of mitochondrial iron-sulfur enzymes in the macrophage effector cells. J Immunol 1988; 141: 2407-12. 
[16] Ding A, Nathan CF, Stuehr DJ. Release of reactive nitrogen intermediates and reactive oxygen intermediates from mouse peritoneal macrophages: comparison of activating cytokines and evidence for independent production. J Immunol 1988; 141: 2407-12.

[17] Busse R, Mulsch A. Induction of nitric oxide synthase by cytokines in vascular smooth muscle cells. FEBS Lett 1990; 275: 87-90.

[18] Knowles RG, Merrett M, Salter M, Moncada S. Differential induction of brain, lung and liver nitric oxide synthase by endotoxin in the rat. Biochem J 1990; 270: 833-6.

[19] Knowles RG, Salter M, Brooks SL, Moncada S. Antiinflammatory glucocorticoids inhibit the induction by endotoxin of nitric oxide synthase in the lung, liver and aorta of the rat. Biochem Biophys Res Commun 1990, 172: 1042-8.

[20] Moncada S, Higgs A. The L-arginine-nitric oxide pathway. N Engl J Med 1993; 329: 2002-12.

[21] Thomsen LL, Lawton FG, Knowles RG, Beesley JE, RiverosMoreno V, Moncada S. Nitric oxide synthase activity in buman gynecological cancer. Cancer Res 1994; 54: 1352-4.

[22] Guarner C, Soriano G, Tomas A et al. Increased serum nitrite and nitrate levels in patients with cirrhosis: relationship to endotoxemia. Hepatology 1993; 18: 1139-43.

[23] Broughton-Smith NK, Evans SM, Hawkey CJ et al. Nitric oxide synthase activity in ulcerative colitis and Crohn's disease. Lancet 1993; 342: 338-40.

-[24] Moncada S. Significance of endogenous nitric oxide production for the effect of nitrates and in septic shock. Schweiz Rundsch Med Prax 1993; 82: 1154-60.

[25] Radomski MW, Palmer RMJ, Moncada S. Glucocorticoids inhibit the expression of an inducible, but not the constitutive, nitric oxide synthase in vascular endothelial cells. Proc Natl Acad Sci USA 1990; 87: 10043-7.

[26] Förstermann U, Pollock JS, Schmidt HHHW et al. Calmodulin-dependent endothelium-derived relaxing factor/nitric oxide synthase activity is present in the particulate and cytosolic fractions of bovine aortic endothelial cells. Proc Natl Acad Sci USA 1991; 88: 1788-92.

[27] Nathan CF, Stuehr DJ. Does endothelium-derived nitric oxide have a role in cytokine-induced hypotension? J Natl Cancer Inst 1990; 82: 726-8.

[28] Rubanyi GM, Romero JC, Vanhoutte PM. Flow induced release of endothelium-derived relaxing factor. Am J Physiol 1986; 250: 41145-9.

[29] La Montagne D, Pohl U, Busse R. Mechanical deformation of vessel wall and shear stress determine the basal release of endothelium-derived relaxing factor in the intact rabbit coronary vascular bed. Circ Res 1992; 70: 123-30.

[30] Waldman SA, Murad F. Cyclic GMP synthesis and function. Pharmacol Rev 1987; 39: 163-96.

[31] Ishii K, Chang B, Kerwin JF Jr et al N omega-Nitro-Larginine: a potent inhibitor of endothelium-derived relaxing factor formation. Eur J Pharmacol 1990; 176: 219-23.

[32] KatuSic ZS, Vanhoutte PM. Endothelium-dependent contractions to N-G-monomethyl-L-arginine in canine basilar artery. In: Rubanyi GM, Vanhoutte PM, eds. Endothelium-derived relaxing factors. Basel: Karger, 1990: 95-9.

[33] Cosentino F, Sill JC, Katuse ZS. Endothelial L-arginine pathway and relaxations to vasopressin in canine basilar artery. Am J Physiol 1993; 264: H413-8.

[34] Rees DD, Palmer RM, Moncada S. Role of endotheliumderived nitric oxide in the regulation of blood pressure. Proc Natl Acad Sci USA 1989; 86: 3375-8.

[35] Vallance P, Collier J, Moncada S. Effects of endotheliumderived nitric oxide on peripheral arteriolar tone in man. Lancet 1989; 2: 997-1000.

[36] Vallance P, Collier J, Moncada S. Nitric oxide synthesized from $\mathrm{L}$-arginine mediates endothelium-dependent dilatation in human veins. Cardiovasc Res 1989; 23: 1053-7.

[37] Calver A, Collier J, Moncada S, Vallance P. Effect of local intraarterial of $\mathrm{N}^{\mathrm{G}}$-monomethyl-L-arginine in patients with hypertension: the nitric oxide dilator mechanism appears abnormal. J Hypertens 1992; 10: 1025-31.
[38] Rees DD, Palmer RMJ, Schulz R, Hodson HF, Moncada S. Characterization of three inhibitors of endothelial nitric oxide synthase in vitro and in vivo. J Pharmacol 1990; 101: $746-52$.

[39] Richard V, Tanner FC, Tschudi M, Luscher TF. Different activation of L-arginine pathway by bradykinin, serotonin, and clonidine in coronary arteries. Am J Physiol 1990; 259: H1433-9.

[40] Flavahan NA, Shimokawa H, Vanhoutte PM. Pertussis toxin inhibits endothelium-dependent relaxations to certain agonists in porcine coronary arteries. J Physiol 1989; 408: 549-60.

[41] KatuSE ZS. Endothelial L-arginine pathway and regional cerebral arterial reactivity to vasopressin. Am J Physiol 1992; 262: H1557-62.

[42] Shibano T, Codina J, Birnbaumer L, Vanhoutte PM. Pertussis toxin-sensitive G-proteins in regenerated endothelial cells after balloon denudation of porcine coronary artery. Am J Physiol 1994; 267: H207-12.

[43] Feletou M, Vanhoutte PM. Endothelium-dependent hyperpolarization of canine coronary smooth muscle. Br J Pharmacol 1988; 93: 515-24.

[44] Komori K, Lorenz RR, Vanhoutte PM. Nitric oxide, acetylcholine, and electrical and mechanical properties of canine arterial smooth muscle. Am J Physiol 1988; 255: H207-12.

[45] Vanhoutte PM. Other endothelium-derived vasoactive factors. Circulation 1993; 87 (Suppl V): V-9-17.

[46] Tare M, Parkington HC, Coleman HA, Neild TO, Dusting GJ. Hyperpolarisation and relaxation of arterial smooth muscle caused by NO derived from the endothelium. Nature 1990; 346: 69-71.

[47] Standen NB, Quayle JM, Davies NW et al. Hyperpolarising vasodilators activate ATP-sensitive $\mathrm{K}^{+}$channels in arterial smooth muscle. Science $1989 ; 245: 177-80$.

[48] Busse R, Luckhoff A, Bassenge E. Endothelium-derived relaxant factor inhibits platelet activation. Naunyn Schmiedebergs Arch Pharmacol 1987; 336: 566-71.

[49] Radomski MW, Palmer RMJ, Moncada S. The anti-aggregating properties of vascular endothelium: interactions between prostacyclin and nitric oxide. Br J Pharmacol 1987;92:639-46.

[50] Radomski MW, Palmer RMJ, Moncada S. Endogenous nitric oxide inhibits human platelet adhesion to vascular endothelium. Lancet $1987 ; 2: 1057-68$.

[51] Macdonald PS, Read MA, Dusting GJ. Synergistic inhibition of platelet aggregation by endothelium-derived relaxing factor and prostacyclin. Thromb Res 1988; 49: 437-49.

[52] Radomski MW, Vallance P, Whitley G, Foxwell N, Moncada S. Platelet adhesion to human vascular endothelium is modulated by constitutive and cytokine induced nitric oxide. Cardiovase Res 1993; 27: 1380-2.

[53] Radomski MW, Palmer RMJ, Moncada S. An L-arginine: nitric oxide pathway present in human platelets regulates aggregation. Proc Natl Acad Schi USA 1990; 87: 5293-7.

[54] Forstermann U, Mugge A, Alheid U et al. Selective attenuation of endothelium-mediated vasodilation in atherosclerotic human coronary arteries. Circ Res 1988; 62: 185-90.

[55] Yang Z, von Segesser L, Bauer E et al. Different interactions of platelets with arterial and venous coronary bypass vessels. Lancet 1991; 337: 939-43.

[56] Houston DS, Shepherd JT, Vanhoutte PM. Adenine nucleotides, serotonin and endothelium-dependent relaxations to platelets. Am J Physiol 1985; 248: H389-95.

[57] Shimokawa H, Flavahan NA, Vanhoutte PM. Natural course of the impairment of endothelium-dependent relaxations after balloon endothelium-removal in porcine coronary arteries. Circ Res 1989; 65: 740-53.

[58] Golino P, Piscione F, Willerson JT et al. Divergent effects of serotonin on coronary-artery dimensions and blood flow in patients with coronary atherosclerosis and control patients. N Engl J Med 1991; 324: 641-8.

[59] Luscher TF, Diederich D, Siebenmann R et al. Difference between endothelium-dependent relaxations in arterial and in venous coronary bypass grafts. N Engl J Med 1988; 319: 462-7. 
[60] Yang Z, Siebenmann RP, van Segesser L, Stulz P, Turina M, LUscher TF. Endothelium-dependent inhibition and direct activation of platelet vessel wall interaction by thrombin: role of thromboxane inhibitors. Circulation 1994; 89: 2266-72.

[61] Bath PMW, Hassall DG, Cladwin A-M, Palmer RMJ, Martin JF. Nitric oxide and prostacyclin: divergence of inhibitory effects on monocyte chemotaxis and adhesion to endothelium in vitro. Arterioscler Thromb 1991; 11: 254-60.

[62] Kubes P, Suzuki M, Granger DN. Nitric oxide: an endogenous modulator of leukocyte adhesion. Proc Natl Acad Sci USA 1991; 86: 4651-5.

[63] Lilscher TF, Dubey RK, Espinosa E, Yang Z. Vascular biology of coronary artery and bypass graft disease. Curr Opin Cardiol 1993; 8: 963-74.

[64] Clozel M, Kuhn A, Hefti F. Effect of angiotensin converting enzyme inhibitors and of hydralazine on endothelial function in hypertensive rats. Hypertension 1991; 16: 532-40.

[65] Ross B. The pathogenesis of atherosclerosis-an update. $\mathbf{N}$ Engl J Med 1986; 314: 488-500.

[66] Garg UC, Hassid A. Nitric oxide-generating vasodilators and 8-bromo-cyclic guanosine monophosphate inhibit mitogenesis and proliferation of cultured rat vascular smooth muscle cells. J Clin Invest 1989; 83: 1774-7.

[67] Dubey OB, Luscher TF. Nitric oxide inhibits angiotensin II induced migration of vascular smooth muscle cells. Hypertension 1993; 22: 412.

[68] Castellot JJ, Addonizio ML, Rosenberg RD, Karnovsky MJ. Cultured endothelial cells produce a heparin-like inhibitor of smooth muscle cell growth. J Cell Biol 1981; 90: 372-9.

[69] Hannan RL, Kourembanas S, Flanders KO et al. Endothelia] cells synthesize basic fibroblast growth factor and transforming growth factor beta. Growth Factors 1988; 1: 7-18.

[70] Battegay EJ, Raines EW, Seifert RA, Bowen-Pope DF, Ross R. TGF-beta induces bimodal proliferation of connective tissue cells via complex control of an autocrine PDGF loop. Cell 1990, 63: 515-24.

[71] Dicorleto PE, Fox PL. Growth factor production by endothelial cells. In: Ryan U, editor. Endothelial cells. Vol. II. Boca Raton, Florida: CRC Press, 1990: 51-62.

[72] Dubin D, Pratt RE, Cooke JP, Dzau VJ. Endothelin, a potent vasoconstrictor, is a vascular smooth muscle mitogen. $J$ Vasc Med Biol 1989; 1: 13-7.

[73] Dohi Y, Thiel MA, Buhler FR, Luscher TF. Activation of endothelial L-arginine pathway in pressurized resistance arteries: effect of age and hypertension. Hypertension 1990; 16: $170-9$.

[74] Lüscher TF, Vanhoutte PM. Endothelium-dependent contractions to acetylcholine in the aorta of the spontaneously hypertensive rat. Hypertension 1986; 8: 344-8.

[75] Luscher TF. Endothelium-derived nitric oxide: the endogenous nitrovasodilator in the human cardiovascular system. Eur Heart J 1991; 12 (Suppl E): 2-11.

[76] Tschudi MR, Criscione L, Lulscher TF. Effect of aging in hypertension on endothelial function of rat coronary arteries. J Hypertens 1991; 9: 164-5.

[77] Kelm M, Feelisch M, Krebber T, Motz W, Strauer BE. The role of nitric oxide in the regulation of coronary vascular resistance in arterial hypertension: comparison of normotensive and spontaneously hypertensive rats. J Cardiovasc Pharmacol 1992; 20: 183-6.

[78] Nava E, Noll G, Luscher TF. Increased activity of constitutive nitric oxide synthase in cardiac endothelium in spontaneous hypertension. Circulation 1995; 91: 2310-23.

[79] Nava E, Leone AM, Wiklund NP, Moncada S. Detection of release of nitric oxide by vasoactive substances in the anaesthetized rat. In: Feelisch M, Busse R, Moncada S, editors The biology of nitric oxide. London: Portland Press, 1994: $179-81$.

[80] Nava E, Moreau P, Lascher TF. Basal production of nitric oxide is increased, but inefficacious in spontaneous hypertension. Submitted.

[81] Luscher TF, Vanhoutte PM. Mechanisms of altered endothelium-dependent responses in hypertensive blood vessels.
In: Vanhoutte PM, ed. Relaxing and contracting factors. Clifton, New Jersey: Humana Press, 1988: 495-509.

[82] Luscher TF, Raij L, Vanhoutte PM. Endothelium-dependent vascular responses in normotensive and hypertensive Dahl rats. Hypertension 1987; 9: 157-63.

[83] Linder L, Kiowsky W, Buhler FR, Luscher TF. Indirect evidence for the release of endothelium-derived relaxing factor in human forearm circulation in vivo: blunted response in essential hypertension. Circulation 1990; 81: 1762-7.

[84] Panza JA, Casino PR, Kilcoyne CM, Quyyumi AA. Role of endothelium-dependent vascular relaxation of patients with essential hypertension. Circulation 1993; 87: 1468-74.

[85] Taddei S, Virdis A, Mattei P, Salvetti A. Vasodilation to acetylcholine in primary and secondary forms of human hypertension. Hypertension 1993; 21: 929-33.

[86] Cockcroft JR, Chowienczyk PJ, Banjamin N, Ritter JM. Preserved endothelium-dependent vasodilation in patients with essential hypertension. N Engl J Med 1994; 330: 1036-40.

[87] Osborne JA, Siegman MJ, Sedar AW, Mooers SU, Lefer AM. Lack of endothelium-dependent relaxation in coronary arteries of cholesterol-fed rabbits. Am J Physiol 1989; 256: C591-7.

[88] Shimokawa H, Vanhoutte PM. Dietary $\omega 3$ fatty acids and endothelium-dependent relaxations in porcine coronary arteries. Am J Physiol 1989; 256: H968-73.

[89] Förstermann U, Magge A, Alheid U, Haverich A, Frollich JC Selective attenuation of endothelium-mediated vasodilation in atherosclerotic human coronary arteries. Circ Res 1988; 62: $185-90$.

[90] Ludmer PL, Selwyn AP, Shook TL et al. Paradoxical vasoconstriction induced by acetylcholine in atherosclerotic coronary arteries. N Engl J Med 1986; 315: 1046-51.

[91] Guerra R Jr, Brotherton AF, Goodwin PJ, Clark CR, Armstrong ML, Harrison DG. Mechanisms of abnormal endothelium-dependent vascular relaxation in atherosclerosis: implications for altered autocrine and paracrine functions of EDRF. Blood Vessels 1989; 26: 300-14.

[92] Chester AH, O'Neil GS, Moncada S, Tadjkarimi S, Yacoub MH. Low basal and stimulated release of nitric oxide in atherosclerotic epicardial coronary arteries. Lancet 1990, 336: $897-900$.

[93] Minor RL Jr, Myers PR, Guerra R Jr, Bates JN, Harrison DG. Diet-induced atherosclerosis increases the release of nitrogen from rabbit aorta. J Clin Invest 1990; 86: 2109-16.

[94] Woditsch I, Schror K. Reduced endothelium-dependent relaxation at enhanced NO release in hearts of hypercholesterolaemic rabbits. Br J Pharmacol 1994; 111: 1035-40.

[95] Mügge A, Elwell JH, Peterson TE, Harisson DG. Release of intact endothelium-derived relaxing factor depends on endothelial superoxide dismutase activity. Am J Physiol 1991; 260: 219-25.

[96] Ohara Y, Peterson TE, Harrison DG. Hypercholesterolemia increases endothelial superoxide anion production. J Clin Invest 1993; 91: 2546-51.

[97] Mugge A, Elwell JH, Peterson TE, Hofmeyer TG, Heistad DD, Harrison DG. Chronic treatment with polyethylene glycolated superoxide dismutase partially restores endotheliumdependent vascular relaxations in cholesterol-fed rabbits. Circ Res 1991; 69: 1293-1300.

[98] Simon BC, Cunningham LD, Cohen RA. Oxidized low density lipoproteins cause contraction and inhibit endotheliumdependent relaxation in the pig coronary artery. J Clin Invest 1990; 86: 75-9.

[99] Tanner FC, Noll G, Boulanger CM,Luscher TF. Oxidized lowdensity lipoproteins inhibit relaxations of porcine coronary arteries: role of scavenger receptor and endothelium-derived nitric oxide. Circulation 1991; 83: 2012-20.

[100] Drexler H, Zeiher AM, Meinzer K, Just H. Correction of endothelial dysfunction in coronary microcirculation of hypercholesterolemic patients by L-arginine. Lancet 1991; 338: 1546-50.

[101] Vanhoutte PM, Shimokawa H. Endothelium-derived relaxing factor and coronary vasospasm. Circulation 1989, 80: 1-9. 
[102] Pearson PJ, Schaff HV, Vanhoutte PM. Long-term impairment of endothelium-dependent relaxations to aggregating platelets after reperfusion injury in canine coronary arteries. Circulation 1990; 81: 1921-7.

[103] Wiemer G, Scholkens BA, Becker RH, Busse R. Ramiprilat enhances endothelial autocoid formation by inhibiting breakdown of endothelial derived bradykinin. Hypertension 1991; 18: $558-63$

[104] Mombouli J-V, Nephtali M, Vanhoutte PM. Effects of the converting enzyme inhibitor cilazaprilat 'on endotheliumdependent responses. Hypertension 1991; 18 (Suppl II): II22-9.

[105] Auch-Schwelk W, Bossaller C, Claus M, Graf K, Grafe M, Fleck E. Endothelium-dependent relaxations to angiotensin converting enzyme inhibitors in isolated coronary arteries stimulated with bradykinin. J Cardiovasc Pharmacol 1992; 20 (Suppl 9): \$62-7.

[106] Yang Z, Arnet U, von Segesser L, Siebenmann R, Turina $M$, Luscher TF. Different effects of angiotensin-converting enzyme inhibition in human arteries and veins. $J$ Cardiovase Pharmacol 1993; 22 (Suppl 5): S17-22.

[107] Clozel M, Kuhn H, Hefti F, Baumgartner HR. Endothelial dysfunction and subendothelial monocyte macrophages in hypertension: effect of angiotensin converting enzyme inhibition. Hypertension 1991; 18: 132-41.

[108] Becker RHA, Wiemer G, Linz W. Preservation of endothelial function by ramipril in rabbits on a long-term atherogenic diet. J Cardiovasc Pharmacol 1991; 18 (Suppl2): S110-5.

[109] Ontkean MT, Gay R, Greenberg B. Effects of chronic captopril therapy on endothelium derived relaxing factor activity in heart failure. J Am Coll Cardiol 1992; 19 (Suppl A): 768-74.

[110] Raguki E, Krieger J, Wang DS, Dzau VJ, Pratt RE. Induction of angiotensin converting enzyme in neointima after balloon injury. Circulation 1991; 84 (Suppl II): II-113.

[111] Powell JS, Clozel JP, Muller RKM et al. Inhibitors of angiotensin-converting enzyme prevent myointimal proliferation after vascular injury. Science $1989 ; 245: 186-8$.

[112] Farhy RD, Ho KL, Carretero OA, Scicli AG. Kinins mediate the antiproliferative effect of ramipril in rat carotid artery. Biochem Biophys Res Commun 1992; 182: 283-8.
[113] Mombouli JV, Vanhoutte PM. Kinins and endotheliumdependent relaxations to converting enzyme inhibitors in perfused canine arteries. J Cardiovase Pharmacol 1991; 18: 926-7.

[114] James IM, Dickenson EJ, Burgoyne W et al. Treatment of hypertension with captopril: preservation of regional blood flow and reduced platelet aggregation. J Hum Hypertens 1988; 2: 21-5.

[115] Someya N, Morotomi Y, Kodama K et al Suppressive effects of captopril on platelet aggregation in essential hypertension. J Cardiovasc Pharmacol 1984; 6: 840-3.

[116] Xiong Y, Deng H-W, Li Y-J, Chen X. Nitric oxide mediates the protective effect of ramiprilat against damages of rabbit aortic endothelium by oxygen free radicals. Zhongguo Yaolixue Yu Dulixue Zazhi 1994; 8: 241-5.

[117] SOLVD Investigators. Effect of enalapril on mortality and the development of heart failure in asymptomatic patients with reduced left ventricular fractions. $N$ Engl J Med 1992; 327: 685-91.

[118] Yusuf S, Pepine CJ, Garces C et al Effect of enalapril on myocardial infarction and unstable angina in patients with low ejection fractions. Lancet 1992; 340: 1173-8.

[119] Pfeffer MA, Braunwald E, Moye L et al., on behalf of the SAVE Investigators. Effect of captopril on mortality and morbidity in patients with left ventricular dysfunction after myocardial infarction. N Engl J Med 1992; 327: 669-77.

[120] The Acute Infarction Ramipril Efficacy (AIRE) Study Investigators. Effect of ramipril on mortality and morbidity of survivors of acute myocardial infarction with clinical evidence of heart failure. Lancet 1993; 342: 821-8.

[121] Mombouli JV, Vanhoutte PM. Heterogeneity of endothelium-dependent vasodilator effects of angiotensin-converting enzyme inhibitors: role of bradykinin generation during ACE inhibition. J Cardiovasc Pharmacol 1992; 20 (Suppl 9): S74-82.

[122] Ryan US, Avolomin P, Hayes B, Broschat KO. Signal transduction in endothelial cells. In: Ryan US, Rubanyi GM, eds. Endothelial regulation of vascular tone. Marcel Dekker, Inc., 1992. 